\title{
Molecular detection and characterisation of bipartite begomoviruses associated with cucurbitaceous vegetables in Sri Lanka
}

\author{
W.M.E.K. Bandaranayake ${ }^{1}$, W.A.R.T. Wickramaarachchi ${ }^{1 *}$, H.A.M. Wickramasinghe ${ }^{2}$, R.G.A.S. \\ Rajapakshe $^{1}$ and D.M.K.K. Dissanayake ${ }^{1}$ \\ ${ }^{I}$ Horticultural Crop Research and Development Institute, Gannoruwa, Peradeniya. \\ ${ }^{2}$ Department of Agricultural Biology, Faculty of Agriculture, University of Peradeniya, Peradeniya.
}

\begin{abstract}
Begomovirus infection is one of the major problems associated with cucurbit cultivation in Sri Lanka. A study was conducted to detect bipartite begomoviruses associated with cucurbits in the country. Cucumber, gherkin, pumpkin, bitter gourd, ridge gourd and snake gourd samples showing viral like symptoms of leaf mosaic, upward leaf curling, stunting, rosetting, puckering and fruit malformation were found to be infected with begomovirus. However, only cucumber and gherkin samples were detected to be infected with bipartite begomoviruses with both A and B genomes. All the other samples were detected as infected with monopartite begomoviruses with A genome. The sequence comparison of the coat protein gene of DNA-A in bipartite begomovirus associated with cucumber and gherkin showed a $97 \%$ nucleotide identity with the Tomato Leaf Curl New Delhi Virus (ToLCND) (KP868764). The phylogenetic analysis of the cucumber isolate was distinct from all the other viruses; however clustered with different ToLCND viruses. DNA-B showed $90 \%$ identity with the Bhendi Yellow Vein Mosaic Virus (BYVMV) (JQ359517). This new isolate was named as Tomato Leaf Curl New Delhi Virus-Cucumber [Sri Lanka: 2014]. This is the first known bipartite begomovirus associated with cucurbits in Sri Lanka.
\end{abstract}

Keywords: Begomovirus, Bhendi Yellow Vein Mosaic Virus, cucurbits, Tomato Leaf Curl New Delhi Virus.

\section{INTRODUCTION}

Begomoviruses belonging to the family Geminiviridae are among the most devastating pathogens of a variety of cultivated crops including maize, cassava, bean, squash, cucurbits, tomato, sweet potato, cotton and grain legumes in tropical and subtropical regions of the world. All begomoviruses are transmitted by the whitefly
Bemisia tabaci in a persistent, circulative manner to dicotyledonous plants (Rey et al., 2012). Begomoviruses are generally considered to be either monopartite (one ssDNA component called DNA-A) or bipartite (two circular ssDNA components called DNA-A and DNA-B). DNA-A encodes the proteins required for replication, control of gene expression, overcoming host defenses and encapsulation, and insect transmission inducing strong disease symptoms. DNA-B encodes two proteins with functions in intra- and inter-cellular movement in host plants enhancing symptom severity (Padidam et al., 1995; Engel et al., 1998). Most of the monopartite begomoviruses are associated with ssDNA satellite molecules known as alpha and beta satellites (Rey et al., 1995).

DNA-A and DNA- B components of the begomoviruses have very distinct molecular evolution. The analysis highlights that component exchange has played a greater role in diversification of the begomoviruses. Scientists have proposed a hypothesis that DNA-B originated as a satellite that was captured by the monopartite progenitor of all extant bipartite begomoviruses and subsequently evolved to become the integral genome component that is recognised today (Briddon et al., 2010).

Begomoviruses can be subdivided into New World and Old World members according to their geographical origin of isolation. New World includes the geographical regions of Latin America and Meso America; Old World includes Japan, Africa, India and Asia. Nearly all New World viruses have bipartite genomes and the majority of begomoviruses in the Old World apparently have 
monopartite genomes (Zubiaur et al., 1998). However, in the Indo-Pak sub-continent the begomoviruses are highly diverse. A small number of them are bipartite such as the Tomato Leaf Curl New Delhi Virus (ToLCNDV) (Padidam et al., 1995). ToLCNDV from the North India have bipartite genomes while those from the South have monopartite genomes (Borah \& Dasguptha, 2012).

Begomovirus infection is a serious threat to crop cultivation in Sri Lanka and they have been reported from many crops (bean, cassava, tomato and chilli) as Bean Yellowing Virus (Wickramaarachchi et al., 2012), Sri Lanka Cassava Mosaic virus (SLCMV) (Saunders et al., 2002), Tomato Yellow Leaf Curl Gannoruwa Sri Lanka Virus (TYLCGSLV) (Samarakoon et al., 2012) and Chilli Leaf Curl Sri Lanka Virus (ChiLCSLV) (Senanayake et al., 2013). Most of them were reported as closely related with the Indian isolates, indicating trans-boundary movement of the virus due to the close geographical location. Identification of the diversity among begomoviruses in Sri Lanka is important for the management of the disease. The present study was conducted to detect bipartite begomoviruses associated with cucurbits.

\section{METHODOLOGY}

\section{Sample collection}

Leaf samples were collected from infected bitter gourd, ridge gourd, snake gourd, cucumber, gherkin and pumpkin plants, which showed viral like symptoms of leaf mosaic, upward leaf curling, stunting, rosetting, puckering and fruit malformation, from research fields of the Horticultural Crop Research and Development Institute in Gannoruwa, Makandura, Wanathawilluwa and from famer fields (Figure 2). Healthy plant samples were collected from greenhouse-grown plants, which were apparently free from viral symptoms. Total DNA was extracted from infected and healthy plant samples using the modified cetyl trimethyl ammonium bromide (CTAB) method (Lodhi et al., 1994; Wickramaarachchi et al., 2012).

PCR detection of begomovirus DNA-A genome using degenerate primers

A set of degenerate primers (Deng 540-5'TGGACYTTRCAWGGBCCTTCACA 3' and Deng 541-5'TAATATTACCKGWKGVCCSC 3') (Deng et al., 1994) was used to amplify virus DNA-A in the samples. Ten microlitres of reaction mixture comprised $5 \mu \mathrm{L}$ of master mixture (PCR Master mixture-Qiagen), $0.8 \mu \mathrm{L}$ of each primer $(10 \mathrm{mM}), 0.5 \mu \mathrm{L}$ of diluted $(1: 25)$ test DNA suspension and sterile distilled water. The PCR programme used was: one cycle of initial denaturation at $94{ }^{\circ} \mathrm{C}$ for 4 min followed by 30 cycles of denaturation at $94{ }^{\circ} \mathrm{C}$ for $1 \mathrm{~min}$, annealing at $61{ }^{\circ} \mathrm{C}$ for $1 \mathrm{~min}$, extension at $72{ }^{\circ} \mathrm{C}$ for $1.5 \mathrm{~min}$ and a final extension at $72{ }^{\circ} \mathrm{C}$ for 10 min. PCR products were electrophorileat in $1.5 \%$ agarose gel for $1 \mathrm{~h}$ at $80 \mathrm{~V}$ and visualised under UV light using gel documentation apparatus (Figure 1a).

\section{PCR detection of DNA-B genome in begomovirus}

A set of degenerate primers (PCRc15'CTAGCTGCAGCATATTTACRARWATGCCA 3' and PBL1v2040-5' GCCTCTGCAGCARTGRTCKATCTT CATACA 3') (Rojas et al., 1993) was used to amplify DNA-B in the samples. The same test procedures used for the amplification of DNA-A were used to amplify the DNA-B except the primers. The results have been given in Figure $2 b$.

Sequencing and phylogenetic analysis of bipartite begomoviruses in cucumber and gherkin

The PCR products for DNA-A and DNA-B of cucumber and gherkin samples were sent to GeneTech Pvt. Ltd., 54, Kitulwatte Road, Colombo 08, Sri Lanka for bidirectional sequencing. FASTA forms of the resulted sequences were edited and analysed using basic local alignment search tool (BLAST) (Altschul et al., 1990) based on the close sequence identity and the length of the sequences. The phylogenetic analysis was performed to find the relationship of the begomovirus associated with cucumber with other published Gemini viruses using molecular evolutionary genetic analysis (MEGA) 4.0 software by neighbour-joining method (Tamura et al., 2007) at 1000 bootstrap value.

\section{RESULTS}

\section{PCR detection of begomovirus and DNA-A genome}

The PCR assay carried out using a set of degenerate primers successfully amplified the expected DNA-A fragment of $520 \mathrm{bp}$ (Figure 1a) from infected bitter gourd, ridge gourd, snake gourd, cucumber, gherkin and pumpkin samples, confirming the association of begomoviruses in the diseased samples.

\section{PCR detection of DNA-B genome in begomovirus}

Only the infected cucumber and gherkin samples provided the expected DNA-B fragment of $600 \mathrm{bp}$ (Figure 1b). It confirmed the presence of bipartite 


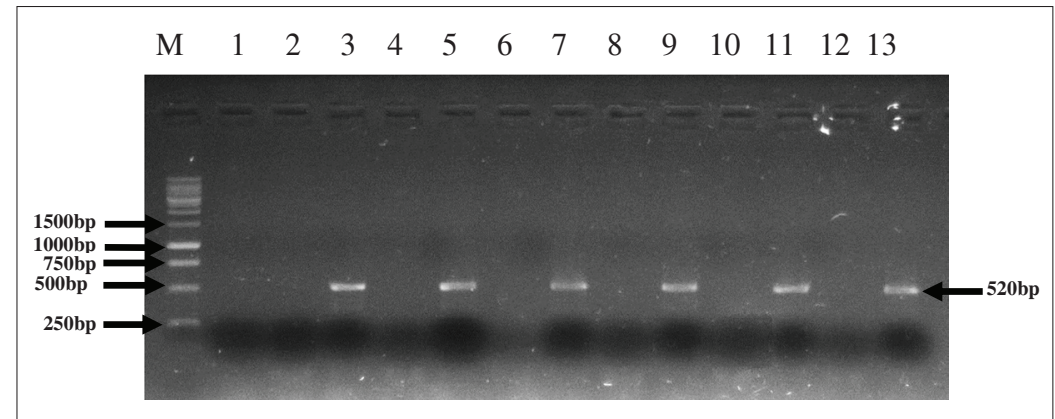

(a)

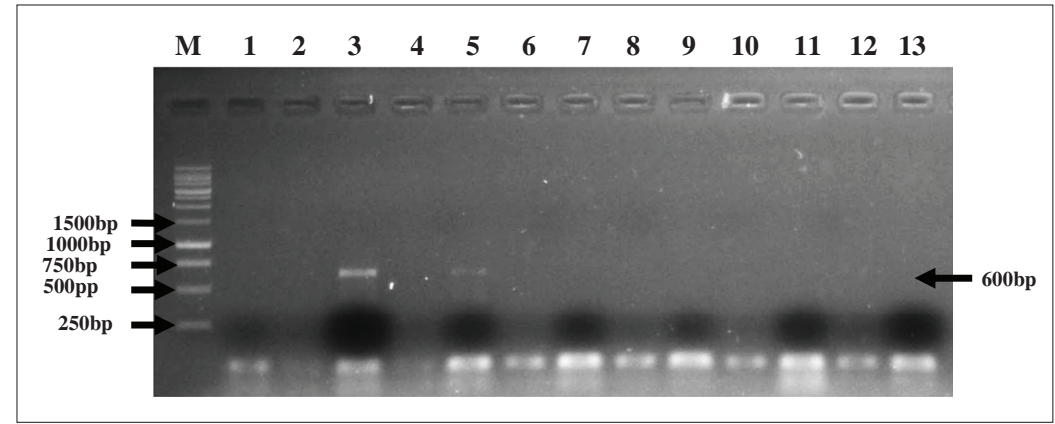

(b)

Figure 1: Molecular detection of (a) DNA-A genome and (b) DNA-B genome in cucurbit samples using degenerate primers

Lane M - 10,000 Kb DNA ladder (promega-G571A); lane 1 - water control; lane 2 - healthy cucumber; lane 3 - infected cucumber; lane 4 - healthy gherkin; lane 5 infected gherkin; lane 6 - healthy pumpkin; lane 7 - infected pumpkin; lane 8 - healthy bitter gourd; lane 9 - infected bitter gourd; lane 10 - healthy ridge gourd; lane 11 infected ridge gourd; lane 12 - healthy snake gourd; lane 13 - infected snake gourd
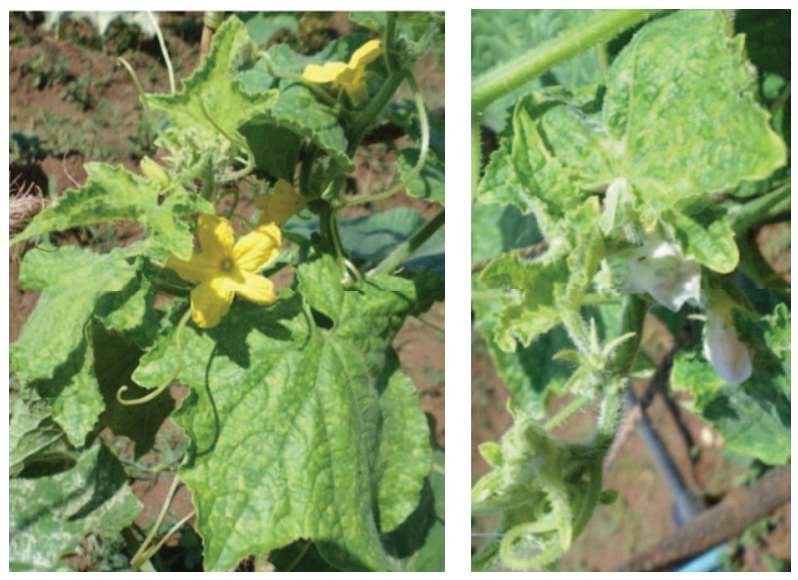

Figure 2: Infected cucumber plants showing leaf yellowing, mosaic, mottling, distortion and upward leaf curling

begomoviruses in the infected cucumber and gherkin samples (Figure 2).

\section{Sequencing and phylogenetic analysis of bipartite begomovirus associated with cucumber and gherkin}

BLAST analysis of the DNA-A coat protein gene fragment of cucumber and gherkin virus isolates showed $97 \%$ nucleotide identity with the ToLCNDV-BG1 (KP868764). A $96 \%$ nucleotide identity was reported with ToLCNDV [Solanum:Pakistan] (DQ116885), ToLCNDV (KC914896), ToLCNDV-Bitter gourd (AM747291) and ToLCNDV - Raebareli (JX232220) viruses reported from India.

BLAST analysis of the DNA-B segment of the cucumber isolate showed $90 \%$ nucleotide identity with the Bhendi Yellow Vein Mosaic Virus movement protein gene (JQ359517) reported from Karnataka, India (Venkataravanappa et al., 2012). This new virus isolate was named as Tomato Leaf Curl New Delhi VirusCucumber [Sri Lanka: 2014] (ToLCNDV-Cucumber [Sri Lanka: 2014]). 


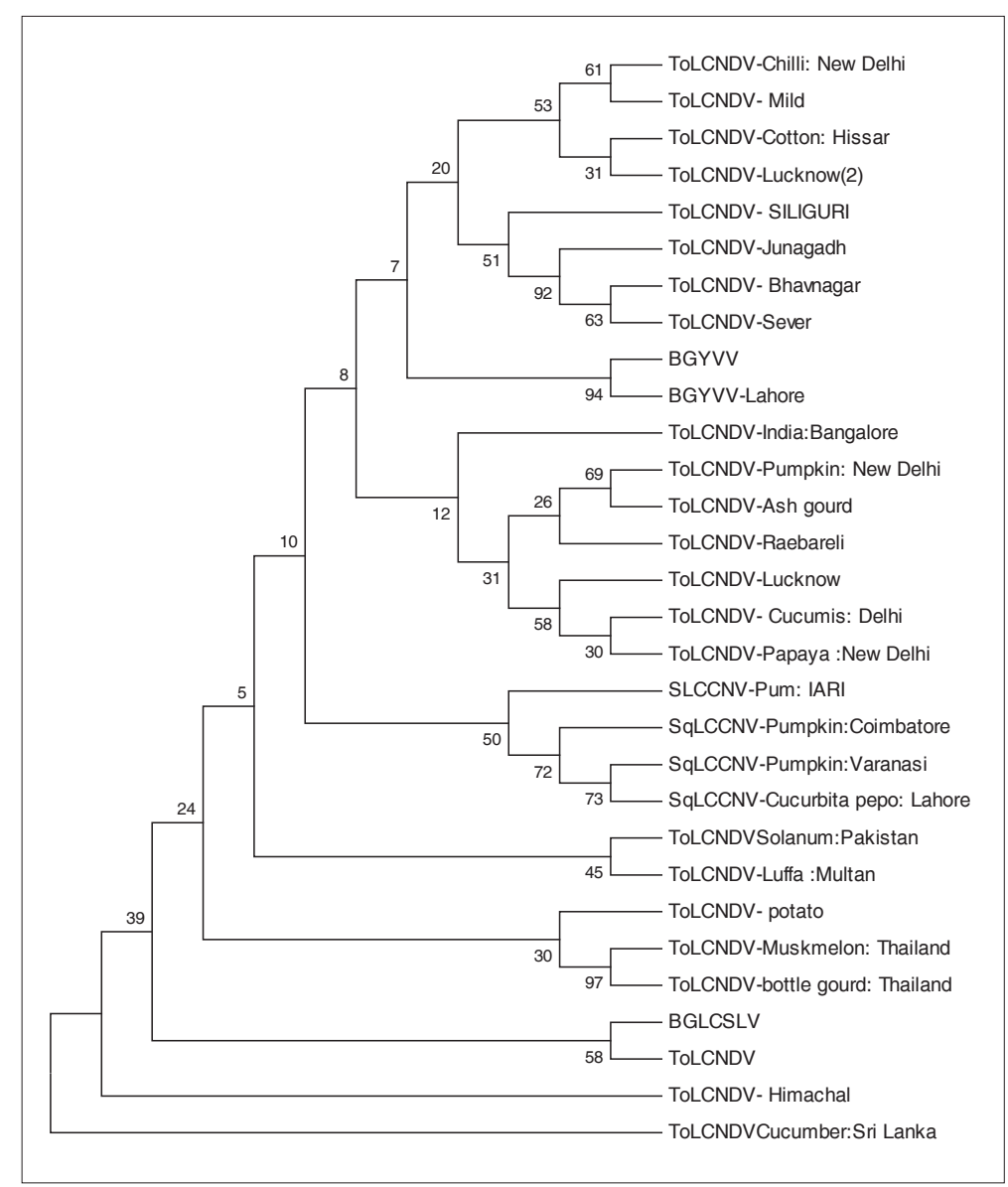

Figure 4: Phylogenetic tree constructed using MEGA 4.0 showing the relationship of cucumber virus isolate (BCSLV) with other begomoviruses

The phylogenetic analysis shows that the present isolate was distinct from all the other viruses. However, it clustered with ToLCNDV isolates from India, Thailand and Pakistan infecting different crops, and Squash Leaf Curl China Virus (SqLCCNV) from India and Pakistan infecting different crops indicating the comparative genetic similarity (Figure 4).

\section{DISCUSSION}

The PCR detection of begomoviruses using degenerate primers confirmed the association of begomoviruses and its DNA-A fragment with the infected bitter gourd, ridge gourd, snake gourd, pumpkin, cucumber and gherkin samples showing viral symptoms of leaf mosaic, upward leaf curling, stunting, rosetting, puckering and fruit malformation. The PCR detection of DNA-B genome using degenerate primers confirmed the association of bipartite begomoviruses with the infected cucumber and gherkin samples. This is the first evidence of the presence of bipartite begomoviruses in cucurbits in Sri Lanka. This result indicates the association of monopartite begomoviruses with infected bitter gourd, ridge gourd, snake gourd and pumpkin samples. The bittergourd sample was previously sequenced and found to be related to Tomato Leaf Curl New Delhi Virus-Bitter Gourd (AM747291) (Bandaranayake et al., 2014).

DNA-A genome of the bipartite ToLCNDVCucumber [Sri Lanka: 2014] was distinct from all the other viruses in phylogenetic analysis, but clustered with the ToLCNDV group infecting different crops. The BLAST analysis reported $97 \%$ neucleotide identity with ToLCNDV, and therefore the ToLCNDV-Cucumber [Sri Lanka: 2014] can be a strain of ToLCNDV. If the sequence shares $94 \%$ genome-wide pairwise identity to all the isolates described for that species, a strain name should then be proposed (Brown et al., 2015). 
DNA-B of the ToLCNDV-Cucumber [Sri Lanka: 2014] showed $90 \%$ nucleotide identity with the Bhendi Yellow Vein Mosaic Virus movement protein gene (BYVMV) (JQ359517) from Karnataka, India (Venkataravanappa et al., 2012). This BYVMV DNA-B showed the highest sequence identity with the ToLCNDV (AY158080). The phylogenetic analysis of the BYVMV isolate was distinct from all the other viruses; but clustered with the ToLCNDV group infecting different crops. The recombination analysis revealed that this isolate has sequences originated from ToLCNDV (Venkataravanappa et al., 2012).

Since BLAST analysis of the ToLCNDV-Cucumber [Sri Lanka: 2014] DNA-A has not shown any relationship with its DNA-B, it can be suggested that the monopartite begomovirus related to ToLCNDV has captured the DNA-B of BYVMV to infect cucumber. Component exchange and recombination has played a far greater role in the diversification of begomoviruses (Kumar et al., 2008; Briddon et al., 2010; Tahir et al., 2010; Venkataravanappa et al., 2015). This study revealed the association of both bipartite and monopartite begomoviruses related to TLCNDV in cucurbit cultivations in Sri Lanka and the risk of trans-boundary movement of viruses from Indian subcontinent due to the close geographical location.

\section{Acknowledgement}

The authors are grateful to all the staff members of the Plant Pathology Division, Horticultural Crop Research and Development Institute, Gannoruwa, Peradeniya for their support in conducting this study.

\section{REFERENCES}

1. Altschul S.F., Gish W., Miller W., Myers E.W. \& Lipman D.J. (1990). Basic local alignment search tools. Journal of Molecular Biology 215: 403 - 410.

2. Bandaranayake W.M.E.K., Wickramarachchi W.A.R.T., Wickramasinghe H.A.M., Rajapakshe R.G.A.S. \& Dissanayake D.M.K.K. (2014). Molecular detection and characterisation of begomoviruses associated with cucurbitaceae vegetables in Sri Lanka. Journal of the National Science Foundation of Sri Lanka 42(3): $265-$ 271.

DOI: http://doi.org/10.4038/jnsfsr.v42i3.7400

3. Borah B.K. \& Dasgupta I. (2012 ). Begomovirus research in India: a critical appraisal and the way ahead. Journal of Biosciences 37(4): 791 - 806.

DOI: http://dx.doi.org/10.1007/s12038-012-9238-y

4. Briddon R.W., Patil B.L., Bagewadi B., Nawaz-ul-Rehman M.S. \& Fauquet C.M. (2010). Distinct evolutionary histories of the DNA-A and DNA-B components of bipartite begomoviruses. BMC Evolutionary Biology 10: 97.

DOI: http://dx.doi.org/10.1186/1471-2148-10-97

5. Brown J.K. et al., (15 authors) (2015). Revision of begomovirus taxonomy based on pairwise sequence comparisons. Archives of Virology 160(6): 1593 - 1619. DOI: http://dx.doi.org/10.1007/s00705-015-2398-y

6. Deng D., Mlgrath P.F., Robinson D.J. \& Harrison B.D. (1994). Detection and differentiation of whitefly transmitted Gemini viruses in plants with vector insects by the polymerase chain reaction with degenerate primers. Annals of Applied Biology 125: 327 - 336.

DOI: http://dx.doi.org/10.1111/j.1744-7348.1994.tb04973.x

7. Engel M., Fernandez O., Jeskeand H. \& Frischmuth T. (1998). Molecular characterization of a new whiteflytransmissible bipartite geminivirus infecting tomato in Panama. Journal of General Virology 79: 2313 - 2317. DOI: http://dx.doi.org/10.1099/0022-1317-79-10-2313

8. Kumar Y., Hallan V. \& Zaidi A.A. (2008). Molecular characterization of a distinct bipartite begomovirus species infecting tomato in India. Virus Genes 37(3): 425 - 431. DOI: http://dx.doi.org/10.1007/s11262-008-0286-1

9. Lodhi M.A., Ye G.N., Weeden N.F. \& Reisch B.I. (1994). A simple and efficient method for DNA extraction from grapevine cultivars, Vitis species and Ampelopsis. Plant Molecular Biology Reporter 12(1): 6 - 13. DOI: http://dx.doi.org/10.1007/BF02668658

10. Padidam M., Beachy R.N. \& Fauquet C.M. (1995). Tomato leaf curl geminivirus from India has a bipartite genome and coat protein is not essential for infectivity. Journal of General Virology 76: 25 - 35. DOI: http://dx.doi.org/10.1099/0022-1317-76-1-25

11. Rey F.A., Heinz F.X., Mandl C., Kunz C. \& Harrison S.C. (1995). The envelope glycoprotein from tick-borne encephalitis virus at $2 \AA$ resolution. Nature 375: 291 - 298. DOI: https://doi.org/10.1038/375291a0

12. Rey M.E.C. et al., (13 authors) (2012). Diversity of dicotyledenous-infecting geminiviruses and their associated DNA molecules in Southern Africa, including the SouthWest Indian Ocean Islands. Viruses 4(9): 1753 - 1791. DOI: http://dx.doi.org/10.3390/v4091753

13. Rojas M.R., Gilbertson R.L., Russel D.R. \& Maxwell D.P. (1993). Use of degenerate, primers in the polymerase chain reaction to detect whitefly transmitted Gemini viruses. Plant Disease 77: 340 - 347.

DOI: http://dx.doi.org/10.1094/PD-77-0340

14. Samarakoon S.A., Balasuriya A., Rajapaksha R.G. \& Wickramarachchi W.A. (2012). Molecular detection and partial characterization of Tomato Yellow Leaf Curl Virus in Sri Lanka. Pakistan Journal of Biological Sciences 15(18): $863-870$.

DOI: http://dx.doi.org/10.3923/pjbs.2012.863.870

15. Saunders K., Salim N., Mali V.R., Malathi V.G., Briddon R., Markham P.G. \& Stanley J. (2002). Characterisation of Sri Lankan Cassava Mosaic Virus and Indian Cassava Mosaic Virus: evidence for acquisition of a DNA B component by a monopartite begomovirus virology. Virology 293(1): $63-74$.

DOI: http://dx.doi.org/10.1006/viro.2001.1251 
16. Senanayake D.M., Jayasinghe J.E., Shilpi S., Wasala S.K. \& Mandal B. (2013). A new begomovirus-betasatellite complex is associated with chilli leaf curl disease in Sri Lanka. Virus Genes 46(1): 128 - 139.

DOI: http://dx.doi.org/10.1007/s11262-012-0836-4

17. Tahir M., Haider M.S. \& Briddon R.W. (2010). Complete nucleotide sequences of a distinct bipartite begomovirus, bitter gourd yellow vein virus, infecting Momordica charantia. Archives of Virology 155(11): 1901 - 1905. DOI: http://dx.doi.org/10.1007/s00705-010-0819-5

18. Tamura K., Dudley J., Nei M. \& Kumar S. (2007). MEGA 4: molecular evolutionary genetics analysis (MEGA) software version 4.0. Molecular Biology Evolution 24: $1596-1599$.

DOI: http://dx.doi.org/10.1093/molbev/msm092

19. Venkataravanappa V., Lakshminarayana R.C.N., Jalali S. \& Krishna R.M. (2012). Molecular characterization of distinct bipartite begomovirus infecting bhendi (Abelmoschus esculentus L.) in India. Virus Genes 44(3): 522 - 535. DOI: http://dx.doi.org/10.1007/s11262-012-0732-y

20. Venkataravanappa V., Reddy C.N., Jalali S. \& Reddy M.K. (2015). Association of tomato leaf curl New Delhi virus DNA-B with bhendi yellow vein mosaic virus in okra showing yellow vein mosaic disease symptoms Acta Virologica 59(2): 125.

21. Wickramaarachchi W.A.R.T., Rajapakshe R.G.A.S., Kumarage A.M., Samarawijaya A.P., Bandaranayake E. \& Premarathna P. (2012). Molecular detection of begomovirus associated with Bean yellowing disease in Sri Lanka. Annals of the Sri Lanka Department of Agriculture 14: $221-231$

22. Zubiaur Y.M., Blas C.D., Quiñones M., Castellanos C., Peralta E.L. \& Romero J. (1998). Havana tomato virus, a new bipartite geminivirus infecting tomatoes in Cuba. Archives of Virology 143: 1757 - 1772.

DOI: http://dx.doi.org/10.1007/s007050050414 